TECHNICAL TRANSACTIONS 2/2018

CHEMISTRY

DOI: $10.4467 / 2353737$ XCT.18.024.7997 SUBMISSION OF THE FINAL VERSION: 9/1/2018

\title{
Przemysław Woliński
}

Radomir Jasiński (radomir@chemia.pk.edu.pl)

Faculty of Chemical Engineering and Technology, Cracow University

of Technology

CheMistry OF 2-ARYL-1-CYANO-1-NITROETHENES.

PART I. SYNTHESIS AND PHYSICAL PROPERTIES

Chemia 2-ARYLO-1-CYJANO-1-NITROETENÓW. CZĘŚĆ I. OTRZYMYWANIE I WŁAŚCIWOŚCI FIZYCZNE

\begin{abstract}
In this paper, we present the methodology of preparation of 2-aryl-1-cyano-1-nitroethenes and the synthesis of their main precursor - nitroacetonitrile. We have also gathered the physical properties of all compounds of this group known in the literature.
\end{abstract}

Keywords: 2-aryl-1-cyano-1-nitroethene, 3-aryl-2-nitro-2-propenenitrile, nitroacetonitrile, ACN, NAN, synthesis

\section{Streszczenie}

W niniejszej pracy przedstawiliśmy metodologię otrzymywania 2-arylo-1-cyjano-1-nitroetenów oraz ich głównego prekursora, jakim jest nitroacetonitryl. Przedstawiliśmy również wlaściwości fizyczne wszystkich znanych w literaturze związków ze wspomnianej grupy.

Słowa kluczowe: 2-arylo-1-cyjano-1-nitroeten, 3-arylo-2-nitro-2-propenonitryl, nitroacetonitryl, synteza 


\section{Introduction}

Conjugated nitroalkenes (CNA) are highly effective synthons in organic synthesis. The presence of the nitro group in CNA molecule provides almost unlimited possibilities for its further functionalization towards, for example, carbonyl compounds (Nef reaction) [1-3], nitrile $\mathrm{N}$-oxides (Mukuiyama reaction) [4], amino alcohols (via a Henry reaction/reduction sequence) $[2,5-7]$, salts and esters of nitronic acids $[2,4,8]$ and many others $[1,2,6,9]$. Additionally, due to their evidently electrophilic character, CNA are valuable reagents in cycloaddition processes leading to five- and six-membered cyclic systems $[1,10,11]$.

In this group of nitro compounds, 2-aryl-1-cyano-1-nitroethenes (ACN) are especially interesting. This type of CNA was first prepared in 1956 by Ried and Köhler [12]. Currently, more than 30 ACNs have been prepared and characterized. It is interesting that most experiments in this area have been performed recently. This confirms a growing interest in ACNs, and so we decide to review all physical and chemical aspects of the ACNs known. In the first part of our study, we characterized the synthetic protocols as well as the physical description of the compounds studied.

\section{Preparation of nitroacetonitrile as a precursor for synthesis of ACNs}

The methodology described in 1956 [12] for the preparation of nitroacetonitrile (NAN) is based on commercially available nitromethane $[13,14]$. In the first step, nitromethane is converted into methazonic acid (MAC) via a condensation reaction catalyzed by $\mathrm{NaOH}$, and in the next step acidification using concentrated $\mathrm{HCl}$ takes place. In this way methazonic acid can be prepared with a yield of $50 \%$ [14].

$$
\mathrm{MeNO}_{2} \underset{45-50^{\circ} \mathrm{C}, \mathrm{H}_{2} \mathrm{O}}{\stackrel{\mathrm{NaOH}}{\longrightarrow}}\left[\begin{array}{r}
\mathrm{N}^{\prime}+ \\
\mathrm{O}^{-}
\end{array}\right] \mathrm{Na}^{+} \frac{\mathrm{MeNO}_{2}}{0^{\circ} \mathrm{C}, \mathrm{H}_{2} \mathrm{O}, 50 \%} \stackrel{\mathrm{N}=}{\mathrm{MAC}_{\mathrm{O}^{-}}^{\mathrm{N}_{+}^{+}}}
$$

Dehydration of MAC leads to the formation of NAN. This process proceeds via a reaction involving thionyl chloride in a dry diethyl ether solution. Under these conditions, the final product may be synthesized with yields up to $47 \%[12,14-18]$. After purification using column chromatography ( $\mathrm{SiO}_{2} /$ benzene) NAN of a purity suitable for use in Knoevenagel condensation is obtained. NAN is a pale yellow, unstable liquid, which at temperatures higher than $50-60^{\circ} \mathrm{C}$ is capable of exploding. Therefore, attempts to purify it via vapour distillation are potentially very dangerous [13].

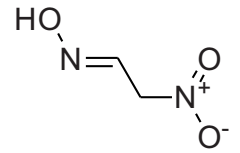

MAC

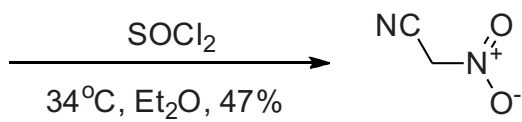

NAN 
Kislyi and coworkers [19] have described an alternative, more effective synthetic way for preparing NAN. In this approach, NAN is synthesized according to a two-stage procedure: (i) nitration of cyanoacetone (CA) in a two-phase system, and next, (ii) deacylation of the nitrocarbonyl intermediate product (NCA).<smiles>CC(=O)CC#N</smiles>

CA<smiles>CC(=O)C(C#N)[N+](=O)[O-]</smiles>

NCA

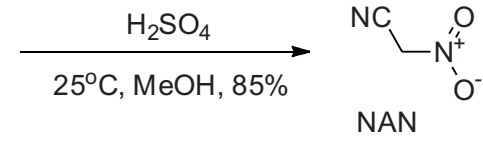

NAN

Unfortunately, no literature examples of a successful repeat of this procedure exist.

Very recently, a new procedure for NAN preparation was reported [20]. Based on ethyl ester of isonitrosocyanacetic acid (INCE), pure NAN was obtained with a moderate yield.
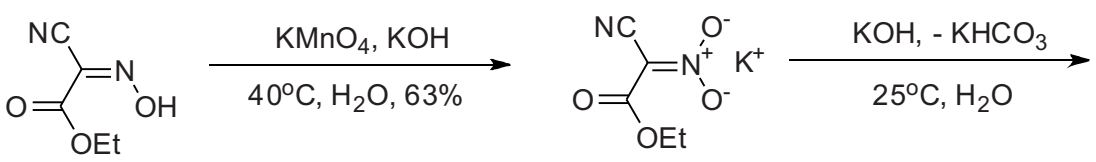<smiles>N#[N+][N+](=O)[O-]</smiles>

INCE

\section{Preparation of ACNs}

The first compounds in the ACN group were prepared by Ried and Köhler [12]. These authors described synthesis based on NAN and a series of aromatic aldehydes in the presence of a catalytic amount of methylamine generated in situ. This way, 11 new compounds $(\mathbf{1}, \mathbf{3}$, 13, 17-21, 24, 28, 29) were prepared with very different yields. An analogous methodology was also applied later in the case of ACNs $2,7, \mathbf{1 0}, \mathbf{1 4}, \mathbf{1 5}, 23$ and 25 [21-24].

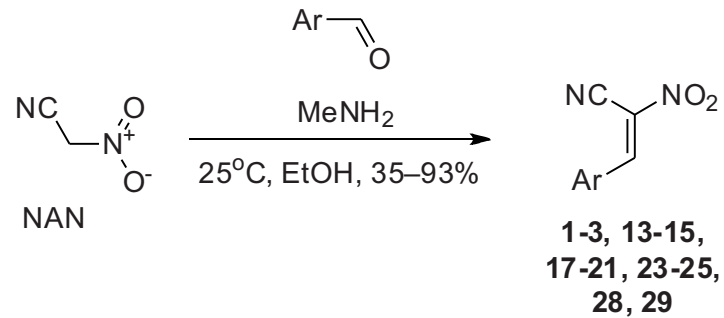

Later $[18,25-27,28]$, other aliphatic and alicyclic amines (n-propylamine, n-pentylamine, morpholine, ethylenediamine, $\beta$-alanine) were also tested as catalysts in similar syntheses. In these syntheses several new compounds were prepared. It is interesting that these series contain many compounds $(\mathbf{2}-4,9, \mathbf{1 1}, \mathbf{1 2}, \mathbf{1 6})$ with electron-withdrawing groups $(\mathrm{F}, \mathrm{Br}$, $\mathrm{COOMe}$ ) in aryl rings, which was not been prepared earlier. 


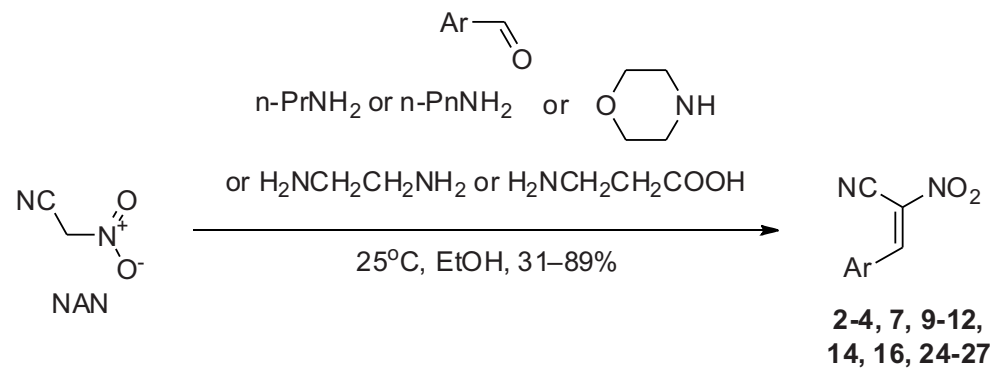

In an alternative protocol, 1-butyl-3-methylimidazolium chloride has been used as a catalyst and as a reaction medium [17]. According to this procedure, six known earlier compounds $(\mathbf{1}-\mathbf{5}, \mathbf{7})$ have been prepared with very high yields $(>92 \%)$.

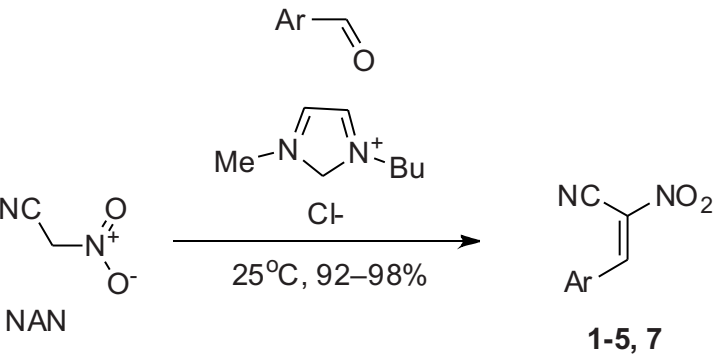

For preparation of CNA 10 containing the EDG dimethylamino group in a phenyl ring, an alternative procedure using various acidic catalysts $\left(\mathrm{A}=\mathrm{SOCl}_{2}, \mathrm{AlCl}_{3}\right.$, 4-toluenesulphonic acid, $\mathrm{HCl}$ ) was developed [29]. In particular, by this method compound $\mathbf{1 0}$ may be obtained with a yield up to $72 \%$.
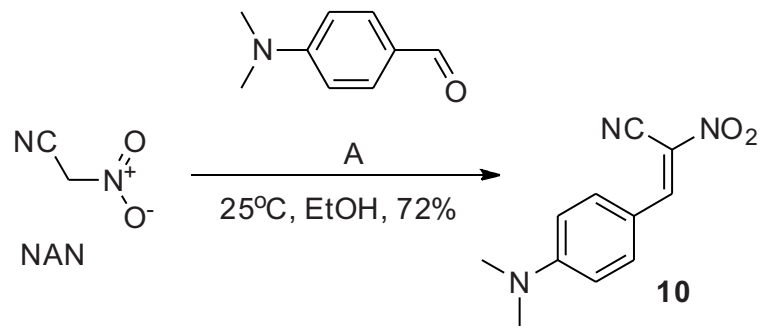

Heterogeneous catalysts have also been applied for the synthesis of ACNs. It was found that in the presence of dolomite $\mathrm{CaMg}\left(\mathrm{CO}_{3}\right)_{2}$ some aromatic aldehydes undergo condensation with the NAN yielding an expected CNA with a high yield [30]. In analogous processes, an $\mathrm{SiO}_{2}$ catalyst was also applied [31].

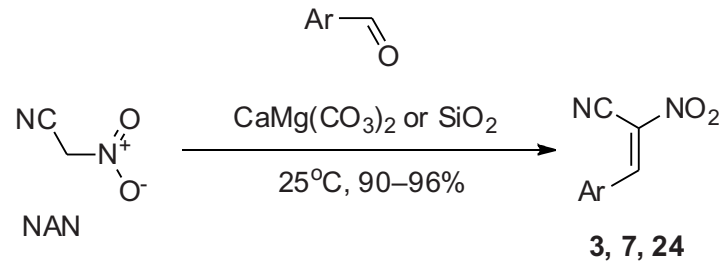


Recently, a "green" protocol for synthesis of series of ACNs has been described by Pizzo et al [32]. According to this procedure, 11 different compounds $(1,3,5-8,14,15,22,24,25)$ were prepared in a water environment after $7 \mathrm{~h}$ with high yields up to $95 \%$.

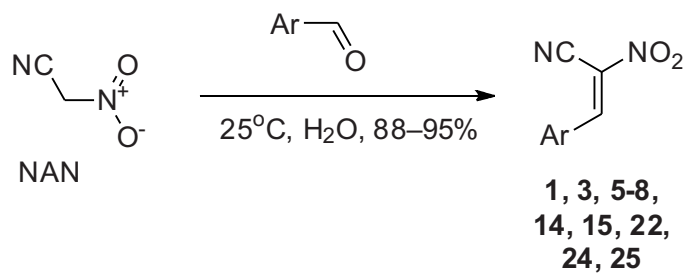

Relatively faster than earlier methods are similar syntheses preformed in the presence of a catalytic amount of ammonium chloride [33]. Microwave irradiation of mixtures of NAN and appropriate aldehydes under these conditions give the expected products after $2-3 \min (!)$.

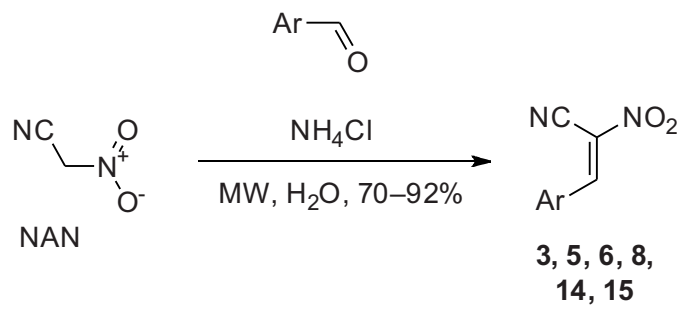

Independently of condensation between NAN and aromatic aldehydes, other strategies have been also tested for synthesis of ACNs. In particular, Blaha et al [34], analogously to earlier studies [35], analysed the possibility of preparing CNA 1 via chloronitration using nitryl chloride. Unfortunately, no attempts to obtain 1 were successful. On the other hand, Ariga et al [36] described an alternative synthetic pathway based on the pyridinium salt of 4-nitroisoxazolin-5(2H)-one. This way, the authors synthesized two ACNs $(1,7)$ with almost quantitative yield. Unfortunately, at this time it is not known whether this is a universal method.
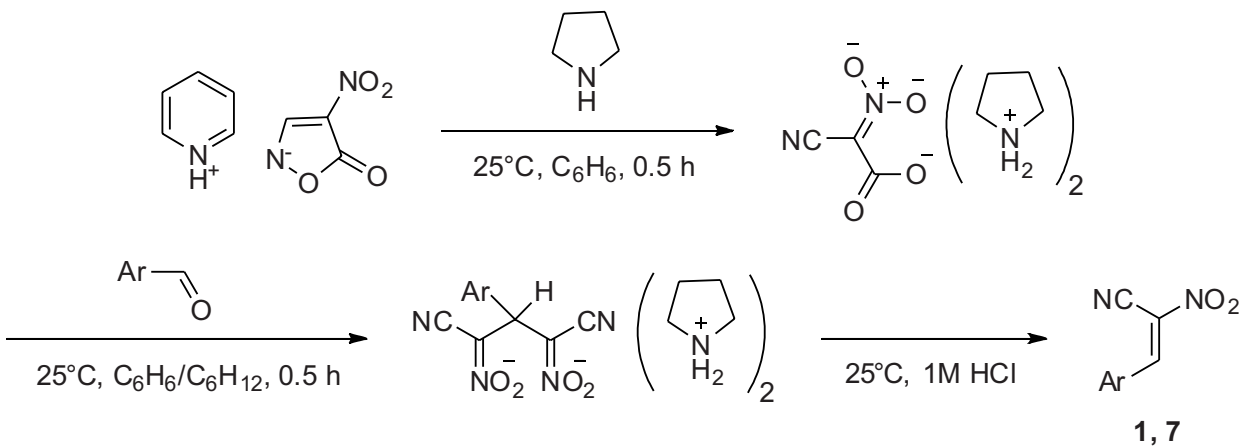

Fundamental physical properties of all known ACNs are collected in Table 1. 


\section{Conclusion}

The literature describes many methods for the preparation of conjugated nitroalkenes (CNA). Most universal strategies are based on the thermal or catalytic decomposition of nitroalkyl esters [37-41] and dehydrohalogenation of 1,2-dihalo-1-nitroethane derivatives $[35,42]$. Unfortunately, all these protocols are inadequate for preparation of 2-aryl-1-cyano1-nitroethenes. For this purpose only Knoevenagel condensation involving nitroacetonitrile is dedicated.

It should be mentioned at this point that most known ACNs were applied for synthesis of different type carbo- and heterocyclic compounds. These issues are the subject of the next part of our study.

\section{References}

[1] Barrett A.G.M., Graboski G.G., Conjugated nitroalkenes: versatile intermediates in organic synthesis, Chemical Reviews, 1986, 86, 751-762.

[2] Ono N., The nitro group in organic synthesis, Wiley-VCH, Weinheim 2001.

[3] Ballini R., Petrini M., Recent synthetic developments in the nitro to carbonyl conversion (Nef reaction), Tetrahedron, 2004, 60, 1017-1047.

[4] Belenkii L.I., [in:] Nitrile oxides, nitrone and nitronates in organic synthesis, Ed. H. Feuer, Wiley, 2007.

[5] Boruwa J., Gogoi N., Saikia P.P., Barua N.C., Catalytic asymmetric Henry reaction, Tetrahedron: Asymmetry, 2006, 17, 3315-3326.

[6] Agrawal J.P., Hodgson R.D., Chemistry of explosives, Wiley, 2007.

[7] Bergmeier S.C., The Synthesis of Vicinal Amino Alcohols, Tetrahedron, 2000, 56, 2561-2576.

[8] Denmark S.E., Cottell J.J., [in:] The chemistry of heterocyclic compounds, Eds. A. Padwa, W.H. Pearson, New York 2002.

[9] Novikov C.C., Shvekhgeimer G.A., Sevastyanova V.V., Shlaposhnikov V.A., Khimiya alifaticheskikh $i$ alitsiklicheskikh nitrosoedinenii, Khimya, Moscov 1974.

[10] Nguyen T.B., Martel A., Gaulon-Nourry C., Dhal R., Dujardin G., 1,3-Dipolar Cycloadditions of Nitrones to Hetero-substituted Alkenes Part 2: Sila-, Thia-, Phospha- and Halo-substituted Alkenes, Organic Preparations and Procedures International, 2012, 44, $1-81$.

[11] Terrier F., Dust J.M., Buncel E., Dual super-electrophilic and Diels-Alder reactivity of neutral $10 \pi$ heteroaromatic substrates, Tetrahedron, 2012, 68, 1829-1843.

[12] Ried W., Köhler E., Königstein F.J., Reacktionen mit Nitro-acetonitril, Liebigs Annalen, 1956, 598, 145-158.

[13] R. Jasiński, Preparatyka alifatycznych nitrozwiązków, RTN, 2013.

[14] Matthews V.E., Kubler D.G., Improved Synthesis of Salts and Esters of Nitroacetic Acid, Journal of Organic Chemistry, 1960, 25, 266-268.

[15] Steinkopf W., Bohrmann L., Das Nitro-acetonitril, Liebigs Annalen, 1908, 41, 1044-1052. 
[16] Kanishchev M.I., Korneeva N.V., Shevelev S.A., Synthesis of 3-amino-5-benzylamino-4nitropyrazole, Bulletin of the Academy of Sciences of the USSR, Division of chemical science, 1986, 35, 2145-2147.

[17] Boguszewska-Czubara A., Lapczuk-Krygier A., Rykala K., Biernasiuk A., Wnorowski A., Popiolek L., Maziarka A., Hordyjewska A., Jasiński R., Novel synthesis scheme and in vitro antimicrobial evaluation of a panel of (E)-2-aryl-1-cyano-nitroethenes, Journal of Enzyme Inhibition and Medical Chemistry, 2016, 31, 900-907.

[18] Jasiński R., Miroslaw B., Demchuk O.M., Babyuk D., Łapczuk-Krygier A., In the search for experimental and quantumchemical evidence for zwitterionic nature of (2E)-3-[4(dimethylamino)phenyl]-2-nitroproprop-2-enenitrile - an extreme example of donor- $\pi$ acceptor push-pull molecule, Journal of Molecular Structure, 2016, 1108, 689-697.

[19] Kislyi V.P., Laikhter A.L., Ugrak B.L., Semenov V.V., Synthesis of a-functional nitro compounds by the nitration of activated carbonyl compounds in a two-phase system, Russian Chemical Bulletin, 1994, 43, 70-74.

[20] Voinkov E.K., Ulomskiy E.N., Rusinov V.L., Savateev K.V., Fedotov V.V., Gorbunov E.B., Isenov M.L., Eltsov O.S., New stable form of nitroacetonitrile, Mendeleev Communications, 2016, 26, 172-173.

[21] Acheson R.M., Dearnaley D.P., Plunkett A.O., Porter V.C., The amino-acid Analogue of Mescaline, Journal of Chemical Sciences, 1963, 0, 2085-2087.

[22] Мечков Ц.А., Аемирева 3.И., Синтез некоторых бисаммониевых солей 2,4-динитро3-(4-фторфенил)глутаронитрила, Журнал органической химии, 1985, 21, 1884-1887.

[23] Baichurin R.I., Aboskalova N.I., Trukhin E.V., Berestovitskaya V.M., Aryl(hetaryl)Containing gem-Cyanonitroethenes: Synthesis, Structure, and Reactions with 2,3-Dimethyl1,3-butadiene, Russian Journal of General Chemistry, 2015, 85, 1845-1854.

[24] Metchkov T., Demireva Z., Die Synthese einiger Bis-Ammoniumsalze von 3,4-Dinitro-8(methoxyphenyl)glutarnitrilen, Zeitschrift für Chemie, 1985, 25, 169-170.

[25] M. Kwiatkowska, Praca doktorska, Politechnika Krakowska 2008.

[26] NesterovV.N.,KislyiV.P.,Timofeeva T.V.,AntipinaM.Yu.,SemenovV.V., trans-1-Cyano-2(2-methoxyphenyl)-1-nitroethylene, Acta Crystallographica Section C, 2000, C56, e107-e108.

[27] Помянская А.С., Перекалин В.В., Абоскалова Н.И., Аемирова 3.И., Сокомова А.Н., АбАулкина 3.А., Химия замещенных цианонитроалкенов II. Синтез и строение гетерилцианонитроалкенов, Журнал органической химии, 1979, 15, 2057-2061.

[28] Troschütz R., Grün L., Synthese von basisch substituierten 5H-Pyrimido[4,5-c]-2benzazepinen, Archiv der Pharmazie, 1993, 326, 857-864.

[29] Абоскалова Н.И., Помянская А.С., Перекамин В.В., Аемирова З.И., Сокомова $\Lambda$.Н., Реакция алкенимирования в присутствии кислотных катализаторов, Журнац органической химии, 1972, 8, 1332-1333.

[30] Tamaddon F., Tayefi M., Hosseini E., Zare E., Dolomite $\left(\mathrm{CaMg}\left(\mathrm{CO}_{3}\right)_{2}\right)$ as a recyclable natural catalyst in Henry, Knoevenagel, and Michael reactions, Journal of Molecular Catalysis A: Chemical, 2013, 366, 36-42. 
[31] Brillon D., Sauvé G., Silica Gel-Catalyzed Knoevenagel Condensation of Peptidyl Cyanomethyl Ketones with Aromatic Aldehydes and Ketones. A Novel Michael Acceptor Functionality for C-Modified Peptides: The Benzylidene and Alkylidene Cyanomethyl Ketone Function, Journal of Organic Chemistry, 1992, 57, 1838-1842.

[32] Amantini D., Fringuelli F., Piermatti O., Pizzo F., Vaccaro L., Water, a clean, inexpensive, and re-usable reaction medium. One-pot synthesis of (E)-2-aryl-1-cyano-1-nitroethenes, Green Chemistry, 2001, 3, 229-232.

[33] Valizadeh H., Mamaghani M., Badrian A., Effect of Microwave Irradiation on Reaction of Arylaldehyde Derivatives with Some Active Methylene Compounds in Aqueous Media, Synthetic Communications, 2005, 35, 785-790.

[34] Bláha I., Lešetický L., Preparation and Z-E isomerization of substituted nitrostyrenes, Collection Czechoslovak Chemical Communication, 1986, 51, 1094-1099.

[35] Shechter H., Conrad F., Daulton A. L., Kaplan R. B., Orientation in Reactions of Nitryl Chloride and Acrylic Systems, Journal of American Chemical Society, 1952, 74, 3052-3056.

[36] Nishiwaki N., Nogami T., Tanaka C., Nakashima F., Inoue Y., Asaka N., Tohda Y., Ariga M., Aplication of Cyano-aci-Nitroacetate to Organic Synthesis. 1. Facile Synthesis of Pentanedinitrile-2,4-dinitronates, Journal of Organic Chemistry, 1999, 64, 2160-2162.

[37] Kącka-Zych A., Domingo L.R., Ríos-Gutiérrez M., Jasiński R., Understanding the mechanism of the decomposition reaction of nitroethyl benzoate through the Molecular Electron Density Theory, Theoretical Chemistry Accounts, 2017, 136, 129.

[38] Kącka A., Jasiński R., A dramatic change of kinetic conditions and molecular mechanism of decomposition processes of nitroalkyl carboxylates catalyzed by ethylammonium cations, Computational and Theoretical Chemistry, 2017, 1104, 37-42.

[39] Kącka A., Jasiński R., Triethylsulfonium and triethylphosphonium cations as novel catalysts for the decomposition process of nitroethyl benzoates, Phosphorus Sulfur and Silicon and the Related Elements, 2017, 192, 1252-1258.

[40] Kącka A., Jasiński R., DFT study of the decomposition reactions of nitroethyl benzoates catalyzed by the 1,3-dimethylimidazolium cation, Current Chemistry Letters, 2017, 6, $15-22$.

[41] Kącka A., Jasiński R., A DFT mechanistic study of thermal decomposition reactions of nitroethyl carboxylates: undermine of pericyclic insight, Heteroatom Chemistry, 2016, 27, 279-289.

[42] Łapczuk-Krygier A., Ponikiewski Ł., Single crystal X-ray structure of (Z)-1-bromo-1-nitro2-phenylethene, Current Chemistry Letters, 2015, 4, 21-26. 


\begin{tabular}{|c|c|c|c|c|c|}
\hline 苂 & 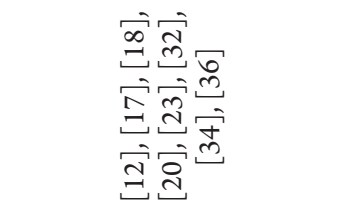 & 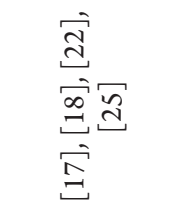 & 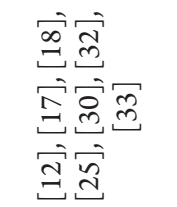 & 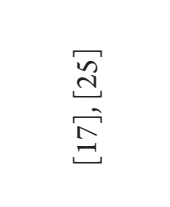 & 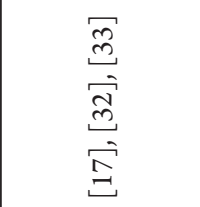 \\
\hline 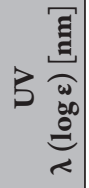 & 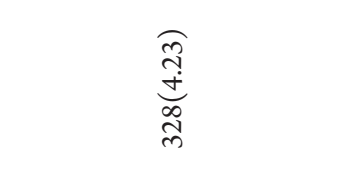 & & & & \\
\hline$\cong \overrightarrow{\tilde{g}}$ & 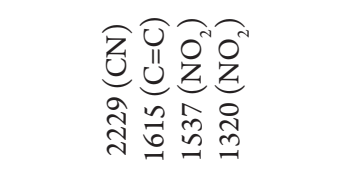 & 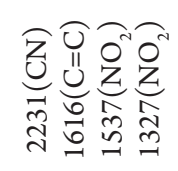 & 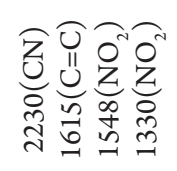 & 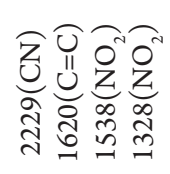 & \\
\hline 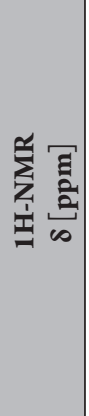 & 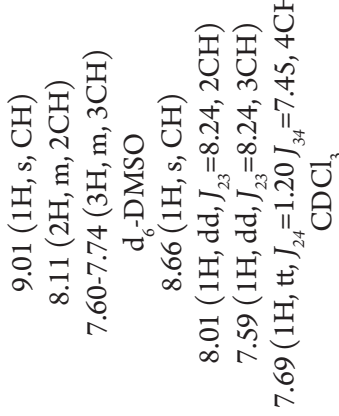 & 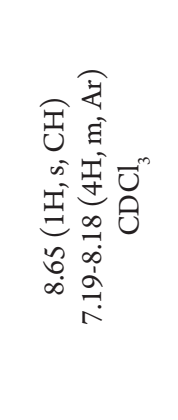 & 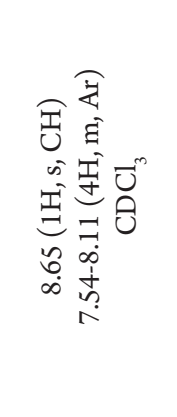 & 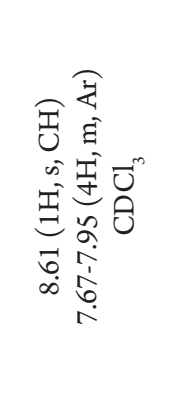 & 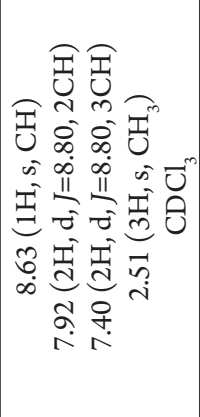 \\
\hline 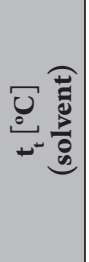 & 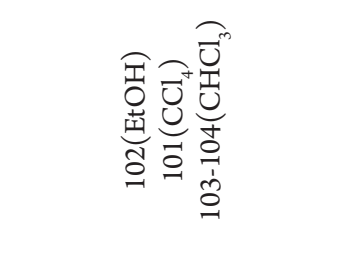 & 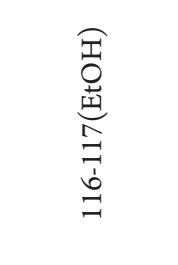 & 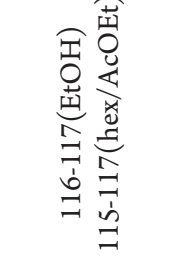 & 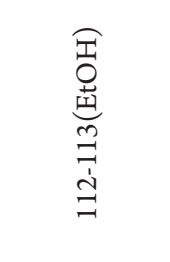 & 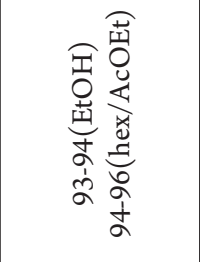 \\
\hline & $\sum_{0}^{0}$ & $\sum_{0}^{0}$ & & 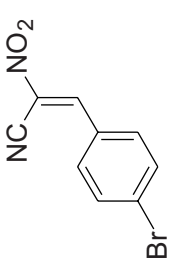 & $\stackrel{0}{2}_{\substack{2 \\
z}}=$ \\
\hline$\dot{\dot{z}}$ & - & $N$ & $m$ & + & in \\
\hline
\end{tabular}




\begin{tabular}{|c|c|c|c|c|c|c|}
\hline 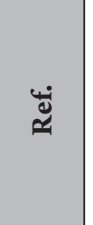 & 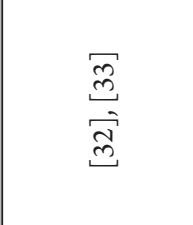 & 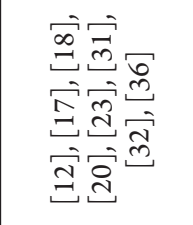 & 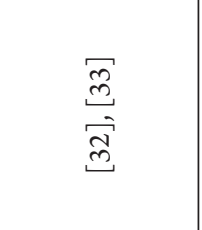 & 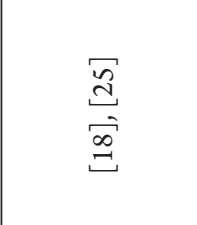 & 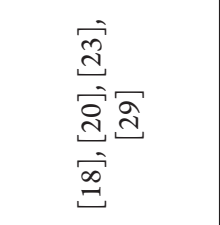 & 胥 \\
\hline 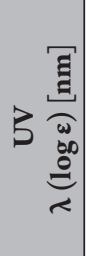 & & 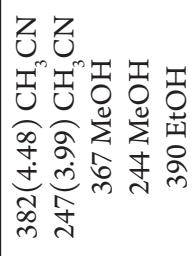 & & & 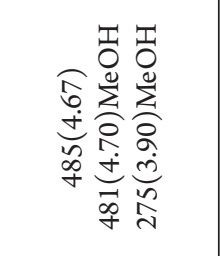 & \\
\hline$\cong \overline{\mathrm{g}}$ & & 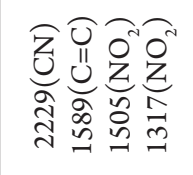 & & 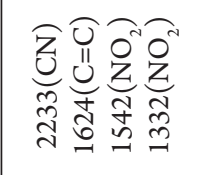 & 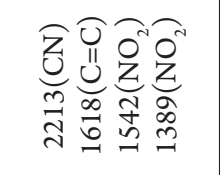 & 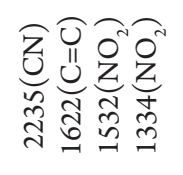 \\
\hline 空 & 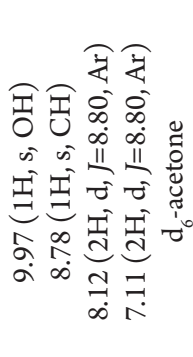 & 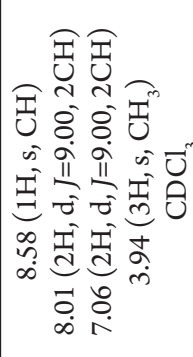 & 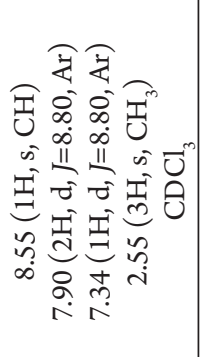 & 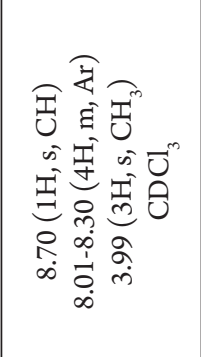 & 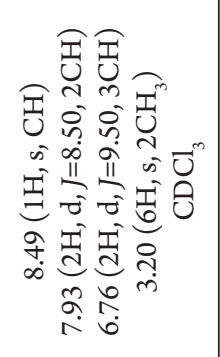 & 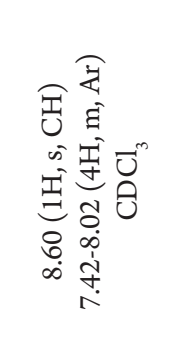 \\
\hline 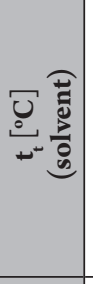 & 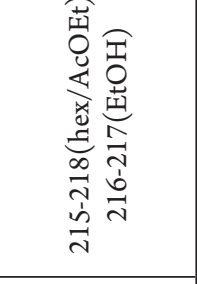 & 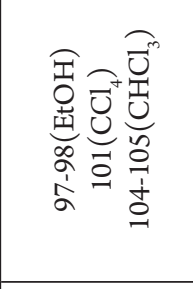 & 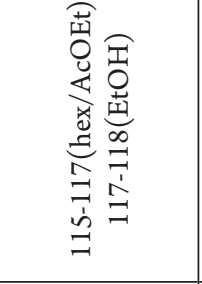 & 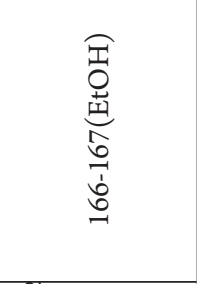 & 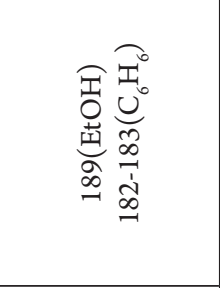 & 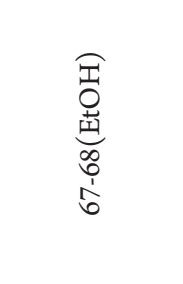 \\
\hline & $\sum_{z}^{\hat{O}_{z}}=$ & $\sum_{z}^{\sum_{z}}=$ & $\left.\sum_{0}^{0}\right\rangle=$ & $\sum_{z}^{2}>$ & & \\
\hline$\dot{\Delta}$ & 0 & $n$ & $\infty$ & $a$ & $\stackrel{\rho}{ }$ & $=$ \\
\hline
\end{tabular}




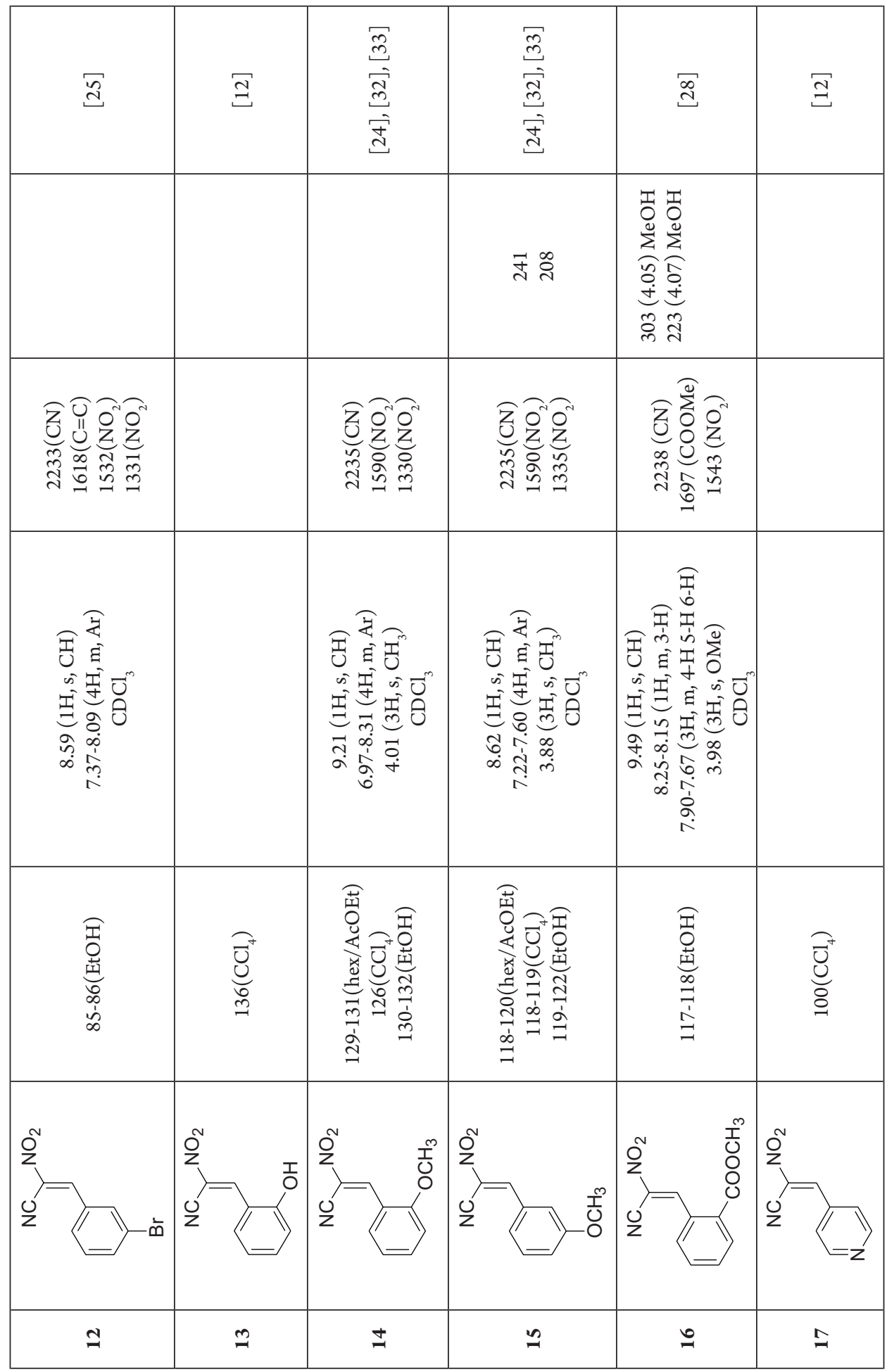




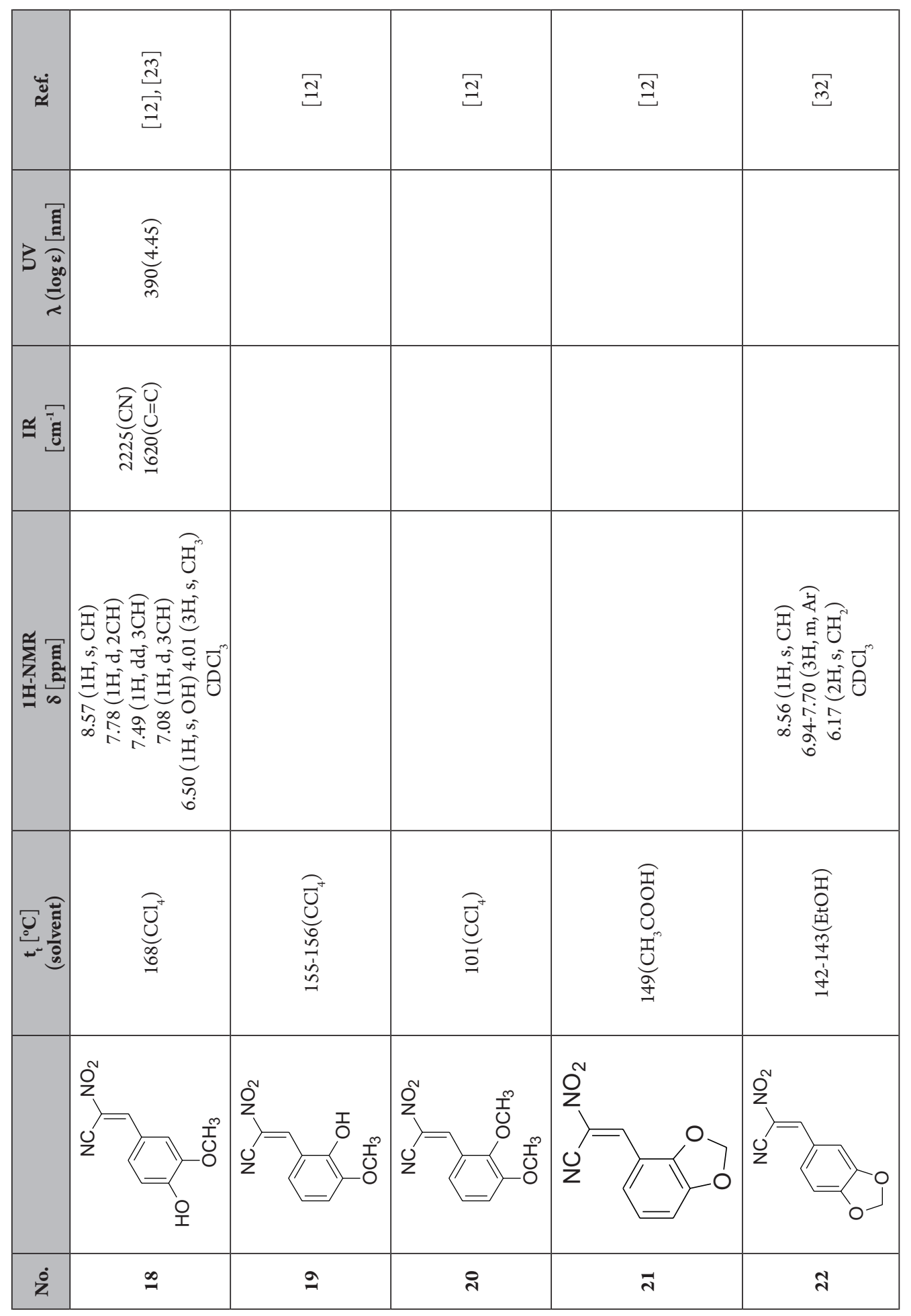




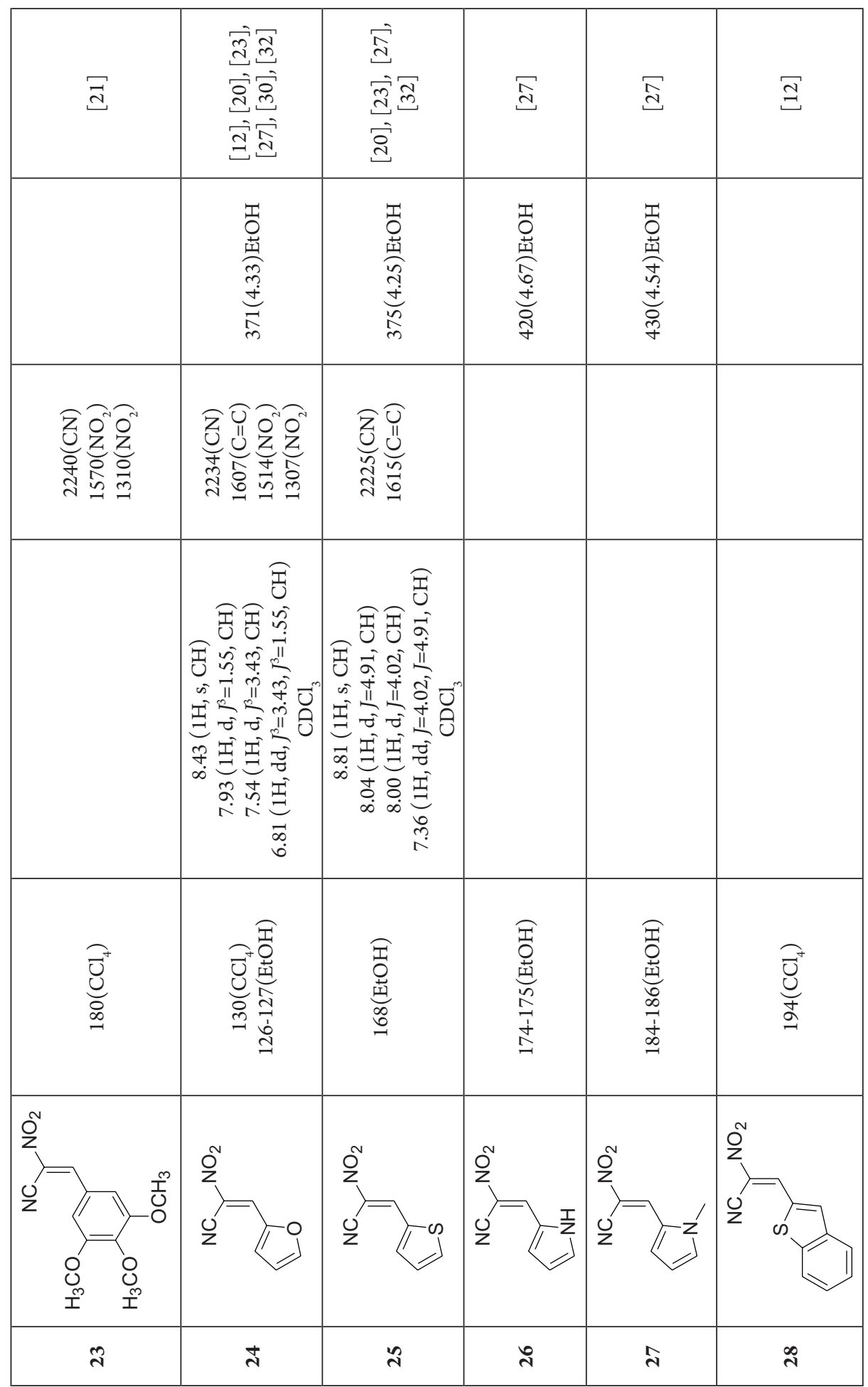




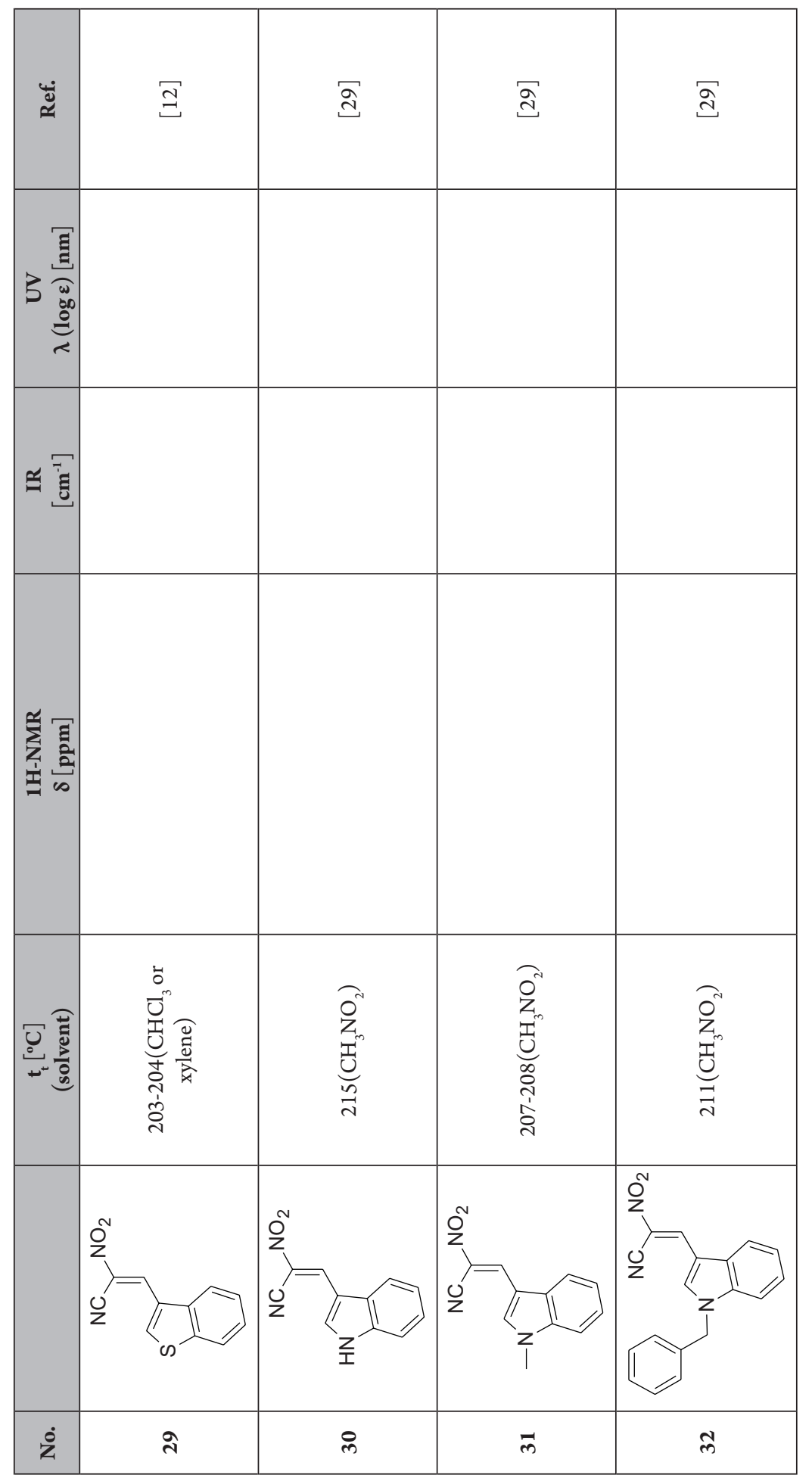

122 